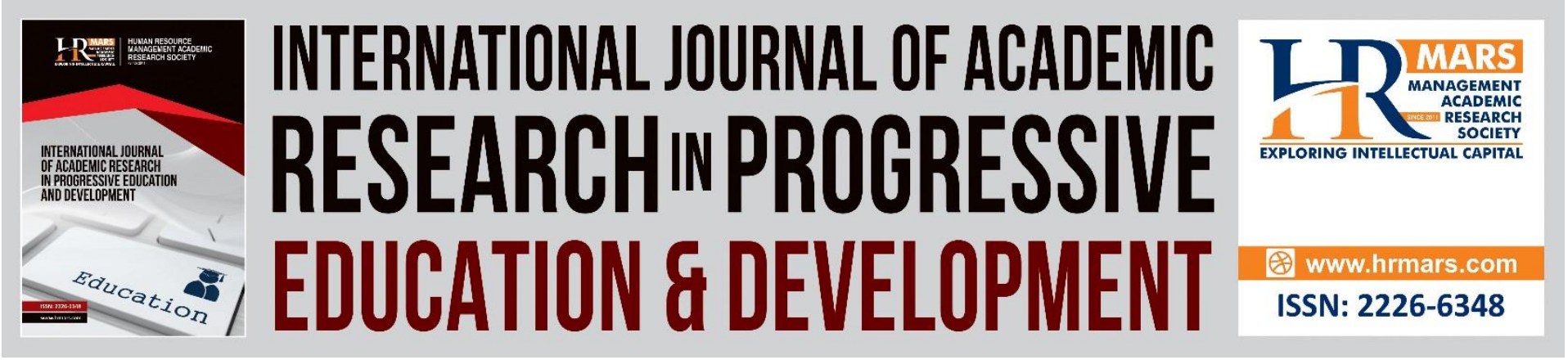

\title{
Implementation of Supermind Textbook by Primary School English Teachers in Melaka
}

Farah Farzana Binti Mohammad Din

To Link this Article: http://dx.doi.org/10.6007/IJARPED/v10-i3/10718

DOI:10.6007/IJARPED/v10-i3/10718

Received: 06 June 2021, Revised: 12 July 2021, Accepted: 30 July 2021

Published Online: 20 August 2021

In-Text Citation: (Din, 2021)

To Cite this Article: Din, F. F. B. M. (2021). Implementation of Supermind Textbook by Primary School English Teachers in Melaka. International Journal of Academic Research in Progressive Education and Development, 10(3), 213-226.

Copyright: (C) 2021 The Author(s)

Published by Human Resource Management Academic Research Society (www.hrmars.com)

This article is published under the Creative Commons Attribution (CC BY 4.0) license. Anyone may reproduce, distribute, translate and create derivative works of this article (for both commercial and non-commercial purposes), subject to full attribution to the original publication and authors. The full terms of this license may be seen

at: http://creativecommons.org/licences/by/4.0/legalcode

\section{Vol. 10(3) 2021, Pg. 213 - 226}

Full Terms \& Conditions of access and use can be found at http://hrmars.com/index.php/pages/detail/publication-ethics 


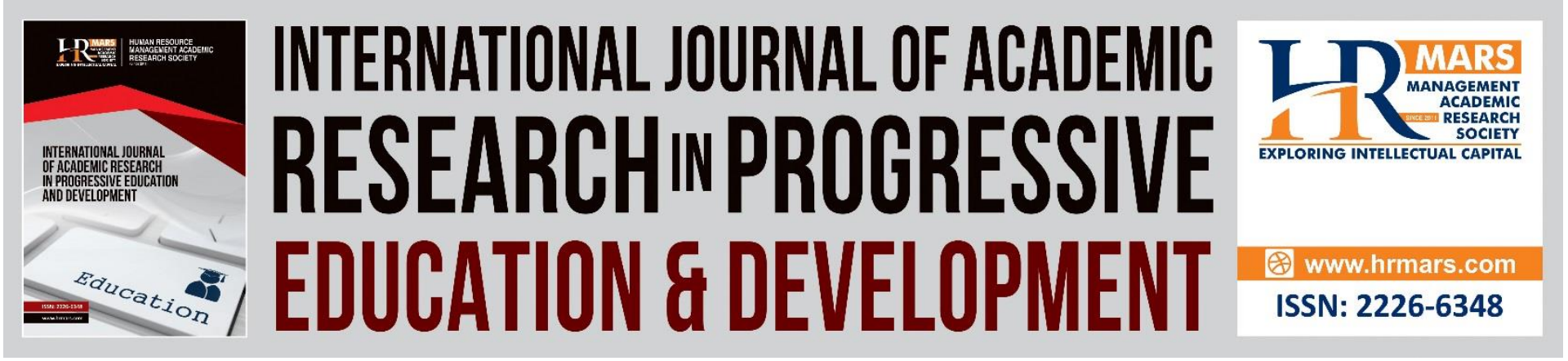

\title{
Implementation of Supermind Textbook by Primary School English Teachers in Melaka
}

\author{
Farah Farzana Binti Mohammad Din \\ Sekolah Kebangsaan Bachang, Melaka
}

\begin{abstract}
This paper discusses on the implementation of Supermind textbook by Year 1 and Year 2 English language teachers. This study had involved 63 Primary school English teachers in Tanjung Zone. A questionnaire with 5 Likert's scale for 15 items had been designed using Google Form and mode was used to determine the highest frequency based on the scale for each item. The items emphases on the listening, reading, writing, vocabulary, pronunciation, and grammar. Based on the results, the respondents agreed that Supermind textbook suitable to be implemented in the classroom. The data gathered provide direct insight for teachers and policymakers about the textbook. Yet, it is strongly recommended that future planning need to be done in selecting a new textbook.
\end{abstract}

Keywords: Supermind Textbook, Implementation, Second Language Acquisition, Low Primary School Teachers

\section{Introduction}

A textbook is one of the important sources and guidance in implementing language programs in education. It is a key on how pupils receive and practice the language. Not only that, it is a medium where the pupils able to have contact with the language besides the input that will be given by their teacher. It also acts as a source and guidance for the teacher to transfer the knowledge and teach the pupils about the language. The reason is that textbook provides the basis for the content, skills and the practice which can be applied in the classroom. In addition, it plays a role as a medium of instruction for the teacher.

Starting from 2013, due to the introduction of Malaysia Education Blueprint 20132025, Malaysia education system had experienced some changes. There are ten shifts in the Blueprint and there are also six aspirations that Malaysia wants to achieve through the education system. One of the aspirations is that Malaysian pupils need to be proficient in Bahasa Malaysia and English Language. In general, the Ministry had set three goals especially for the learning of languages. One of the goals is to develop individuals that are able and proficient enough to work in a globalised economy where the English language is the international language of communication (Ministry of Education Malaysia, 2015). It is not an easy job to fulfil the goal.

As a result, Malaysia Ministry of Education had done a collaboration with Cambridge English and the Ministry of Education. The main purpose of the collaboration is to improve 
the current English Language education in Malaysia to international standards using the Common European Framework of Reference (CEFR). Which means Malaysia's pupils level of English will be on the same level as pupils from other countries that use CEFR. From this, it is clearly can be seen that CEFR is a tool that the government implement to assess the pupils' level of proficiency. Contrary to that, Supermind textbook had been introduced to Year 1 and Year 2 pupils as teaching material for teachers. However, until now, there is no definite guidelines for teacher to refer to assess the pupils based on CEFR.

Nevertheless, Supermind textbook had indicated that there might be some problems related to it. It has been criticised based on its content where the language and culture portrayed are not suitable to the Malaysian context. Nguyen (2015) also mentioned that when the leaners unable to relate to the culture, it will demotivate them if they are required to express themselves within a culture that they do not have any experience with. Therefore, this so that they can relate it with their experience.

Moreover, Hulstijn et al. (2010) pointed out that the actual function of CEFR framework is that it acts as a reference framework for other countries that use English Language as a foreign language to apply it in their curriculum development and assessment. This has also been suggested by Alderson (2016) where he mentioned that those products such as the examination, textbook, and curricula that claimed related to CEFR only acts as a reassurance for teachers. Hence, further study needs to be done as to assure that those products can give benefits to people who are involved with the implementation of the Supermind textbook especially teachers and pupils.

\section{Problem Statement}

In October 2017, aligned with new blueprint which focused on CEFR framework, Deputy Education Minister Datuk P. Kamalanathan told that starting January, imported English textbooks - Super Minds (primary) from Cambridge University Press, and MacMillan's Pulse 2 (secondary), would be used in schools instead of locally produced ones (The Star Online, 2018). Therefore, before the Supermind textbook had been implemented throughout Malaysia, the Ministry of Education had organising workshops for trainers and teachers (Chin, 2018). There is a lot of research done on the implementation of the CEFR program. However, not on Supermind textbook which is something new in Malaysia. There are no other findings which indicate on the implementation of Supermind textbook, leaving no chance for preparation and intervention.

On the other hand, based on research done by Sànchez (2018) in Barcelona, stated that one of the weaknesses of Supermind textbook is that the activities in the textbook are not appropriate with the pupils' age and proficiency level. The textbook is a lack of authenticity to engage the pupils. Besides, the researcher also stated that because of the complexity of the vocabulary, it is frustrated for the pupils as they need extra support. Therefore, research had been conducted in Kawasan Bukit China, Melaka, Malaysia as to see whether the same problems occur at that state.

\section{Purpose of Study \\ Teacher}

The results of this study give teachers a real insight about the Supermind textbook. They can try to find and implement different strategies to cover the weak points of the textbook. This is because, textbooks act as teaching materials where it is a medium for the teacher to deliver 
DEVELOPMENT

Vol. 10, No. 3, 2021, E-ISSN: 2226-6348 @ 2021 HRMARS

his or her lesson. If teachers are unable to deliver the knowledge properly, it might affect the pupils' ability to receive information from the teacher.

\section{Policymakers}

Besides, the findings of this study may help people who are involved during the implementation of new language policy. For instance, it can act as guidelines for policymakers during the process of designing a new syllabus, planning curriculum, and developing materials.

Not only that but it also can inform the policy makers about how the teachers implement the textbook in the classroom. Therefore, policymakers can do future planning when they want to select a new textbook to be used in schools and training for teachers. Based on research done by Uri and Aziz (2018) showed that $38.4 \%$ of the teachers agreed that it is necessary for them to be given training and workshop on CEFR so that it will help them to fully understand and familiar with the concept and usage of CEFR framework.

\section{Research Objective}

To identify the implementation of Supermind textbook in the Year 1 and Year 2 classroom.

\section{Literature review}

Diagram 1

Relationship Between the Implementation of Supermind Textbook and Second Language Acquisition

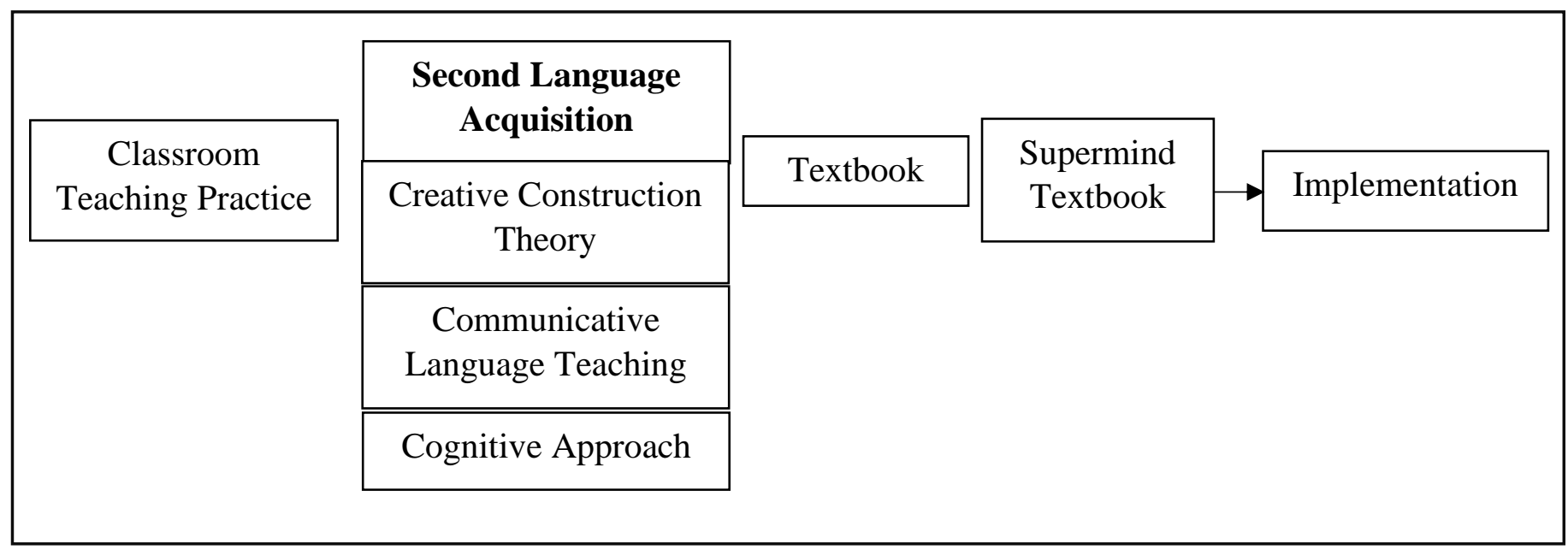

\section{Classroom Teaching Practice}

Research has shown that good and quality instruction in the classroom will help in pupils' learning. This is because, when teachers understand the stages in second language acquisition, it can help the pupils on how they acquire the language in terms of cultural and linguistic. Hong (2008) mentioned that there are six strategies that can be used by teachers in helping the pupils to acquire the second language.

The first strategy is the receptive and pre-production stage. This stage is widely known as "silent period" where the pupils are at the stage in receiving and understand the language. This stage will last from ten hours to six months as they need time to get used to the language. 
The next stage is the early production stage were last for another six months. During this stage, pupils already able to understand and use the word where they can speak in using one-word or two-word phrases.

According to Hong (2008), the third stage is on the speech emergence stage which can be up until one year. At this stage, pupils already able to communicate by using the short phrases and simple sentences. Besides, the intermediate language proficiency stage will happen and might need another year after stage three. Pupils are ready to use more complex sentences, give and share opinions, able to do clarifications and speak at more lengthy sentences.

After all the four stages, in the end, pupils will go to the last stage which is advanced language proficiency. This stage will cost pupils from five to seven years. Teacher will be able to design and upgrade the activities that can enable pupils to fully participate in the classroom.

From all the stages, we can conclude that teacher should have a good understanding of the stage that the pupils are going through at that moment. This is important so that teacher can predict and accept the pupils' proficiency level and able to adapt their instructions. This can motivate the pupils to progress better to the next stage.

\section{What is A Second Language Acquisition?}

Second Language Acquisition (SLA) can be defined as any language that is learnt by an individual in addition to their first or mother tongue language. However, based on Stefánsson and Jóhannsdóttir (2013) stated that SLA is also a process where a person learnt any language as the second, third or fourth language after the first language. Pupils can learn English formally in school or informally during the interaction with society by being a culturally active participant. When the learners actively involved in the learning environment, it can help them to get used to the language through normal daily life. There are three main SLA theories which are Creative Construction Theory, Communicative Language Teaching and Cognitive Approach. Therefore, it is compulsory for teachers to know and understand the theories so that it can be applied during the teaching and learning process.

\section{Relationship Between Textbook and Second Language Acquisition}

In this globalisation era, it is important for teachers and policymakers to know the role of textbook and language acquisition (Trisha, 2016). As mentioned by Johnson (2011) in this millennium time, a young pupil can just use the internet to find out or search new information, however they will still need to refer to books if they want to check information. From this, we can see that books contains correct and actual information which cannot be found from other sources. This had been agreed by Schultan (2013) who mentioned that whatever that is on the internet is not always accurate and true as it can be edited or viral by anyone. Thus, we can say that textbooks have their own role in helping the pupils to acquire new language accurately. Besides, according to Richard (2012), English textbooks able to provide varies activities that can help pupils to learn English in the classroom. Hence, it is aligned with second language theories which are Communicative Language Teaching and Cognitive Approach where the pupils will learn the language unconsciously in the actual situation. 
DEVELOPMENT

Vol. 10, No. 3, 2021, E-ISSN: 2226-6348 @ 2021 HRMARS

\section{Textbook}

\section{Introduction to the Textbook}

Lappalainen (2011) stated that textbook can be defined as any types of books that made and published for education or any books can act as a teaching tool in the classroom. Textbook plays a major role in all language classroom whether in schools, universities, and colleges. According to Lamie (1999), although in the globalization era which technologies are the main medium that helps to increase the quality of teaching materials, textbooks are still growing and in demand. Not only that, a new series of textbook keeps on increasing every year. The reason is that pupils feel secure when they are learning the language using a textbook.

Besides, they also will be able to monitor their own progress and achievement (Razmjoo, 2007). Moreover, Cuuingsworth (1995) also claims that textbook able to help the pupils to do self-directed learning, help teachers to present materials effectively, a source of ideas and activities, act as a reference for pupils, contain syllabus that will help teachers to achieve learning objectives and help the novice teachers to gain confidence to teach the pupils. Hence, from this, we could see that it is not an easy job to develop a textbook that caters to all areas in teaching language. As mention by Hashemi and Rahimpour (2011), the decision of choosing a suitable textbook should be made carefully and systematically, not randomly.

\section{Importance of Textbook}

There is two main importance of textbook. The first one is that textbook act as a supplement for teacher's instructions in teaching and learning process especially in ESL classroom (Cheng et al., 2010). Teacher will use textbook as their guide on how to teach the syllabus and to achieve their goals. This will help teachers to get used and understand the content especially if it is newly introduced by the policymakers. This can also help teachers to have better selfesteem in teaching the pupils as they have a guide and a specific focus on what and how to teach the content of the pupils. Based on the articles written by Mbuva (2016) cited that Rogers (1969) claimed teachers who showed high self-esteem in their daily teaching, they can also give positive effects where it can create high self-esteem in their own pupils. This will help the teachers and pupils to have a positive and active classroom climate. Mentioned by Richards (2012), textbooks are psychologically essential for pupils. The reason is that, without textbooks, pupils will think their learning is not taken seriously.

In addition, textbook can be a major source of cultural elements besides providing the language and current contents related to the language itself. Hence, textbook needs to be authentic enough for the pupils to feel engaged with the language. Based on Kilickaya (2004) authentic materials means that the materials give exposure to real language and use in its own community.

\section{Supermind Textbook}

In Malaysia, aligned with the new curriculum which based on CEFR, Supermind textbook from Cambridge University Press and MacMillan had been used throughout the whole of Malaysia in Year 1 and Year 2 classroom. There is a total of 9 units which need to be divided into half for Year 1 and Year 2. Year 1 will learn from Unit 0 to Unit 4 while Year 2 will focus on Unit 5, $6,7,8$ and 9. Besides, units in Supermind also is under three main themes which are World of Knowledge, World of Stories and World of Self, family and friends. 
The content of the textbook consists of 5 skills which are speaking, listening, reading, writing and language arts. Besides, there is also the introduction of new vocabulary for each unit with the assist of pictures. Not only that, but there are also CDs that had been provided to the teachers. Those CDs can be used in helping them to introduce and teach the contents to the pupils with the help of audio and videos. On the other hand, there are also many illustrations and interesting pictures to help the pupils to use the language in their daily life. Besides, there are also teachers' guidebook and standard documents which can help them in planning a lesson for their pupils. In addition, there is also pupils' workbook that can be used by the pupils for exercises. From this, we can conclude that textbook can affect the pupils teaching and learning process in many ways (Behnke, 2018) and it is vital in helping pupils to learn the language.

\section{Implementation of textbook in the ESL Classroom}

The skills of the English language are the key elements that will help pupils to be proficient in the language. There are four skills in the English language which related to each other. The four skills are:

1. Reading skill: It can help pupils to feel that they are engaging with the topic. Furthermore, according to Trisha (2016) by reading also, it can help pupils to develop and increase their vocabulary skills.

2. Writing skill: According to, Stosky (1983) and Krashen (1984), besides reading the textbooks it will also be able to help the learners in terms of writing. This is because pupils can use ideas from the textbook as a guideline for them to write creative work.

3. Speaking skill: A good textbook should consist of conversation passage, pronunciation exercises etc. which will help to develop their communication skill.

4. Listening skill: According to Trisha (2016), listening skill is the most challenging part of a textbook to develop. Hence, teachers can use audio materials from the textbook as exercises for the pupils to practice their listening skill.

\section{Methodology}

\section{Research Design}

For this research, as to identify the implementation of Supermind textbook in the Year 1 and Year 2 by the teachers in using the Supermind Textbook, a quantitative research design had been utilised. According to a book written by Muijs (2004) cited that quantitative research design is used to explain phenomena through collecting numerical data which will be analyzed based on mathematical methods.

\section{Methodological \\ Paricipants / Samples}

The respondents in this study involved 20 Primary school English teachers. All the schools involved were from Kawasan Bukit Cina, Melaka Tengah, Melaka since these areas were the most populated area in Melaka. The respondents were identified using criterion sampling where it involved teachers who were teaching in Year 1 and Year 2. They are responsible for introducing and implementing the Supermind textbook in the classroom. Furthermore, the teachers are also the one who is responsible to determine the success or failure of the policies introduced by the government. Hence, it is necessary to find out their views on the implementation of the Supermind textbook. In addition, the total number of respondents was 
determined using Krejcie and Morgan's (1970) statistical formula where for 66 samples size is needed for 80 population size.

\section{Instruments}

To identify the implementation, this study uses a questionnaire which had been designed using Google Forms which will be easier to be distributed. The questionnaires were distributed to each school through the District Education office and via schools' email. According to Munn and Dreyer (1990), in large scale surveys, postal questionnaires are by far the cheapest way of gathering information from hundreds or thousands of people. Not only that, the data can be collected in a short amount of time. The questionnaire consists of closeended questions. In the aim to achieve the objectives for the lesson, the questionnaire had been adopted. Some items in the questionnaire were adapted from two published articles by Rahimpour and Hashemi (2011) and Karamifar et al. (2014). Besides, several questionnaires suggested by different scholars were scrutinized. The items selected were relevant to the evaluation and implementation of textbooks. A pilot study was also conducted to make sure the reliability of the instrument.

Likert scale items had been used for sections $A$ and $B$. This study cooperated five-point scale response. The responses are ranging from $5=$ Strongly Agree, $4=$ Agree, $3=$ Neutral, 4 = Disagree, 1 = Strongly Disagree. There are 15 survey questions which concentrate on listening, reading, writing, vocabulary, pronunciation and grammar. It will help to evaluate the implementation of the Supermind textbook in Year 1 and Year 2 classroom.

\section{Data Analysis}

After teachers had answered the survey, all the items had been counted using mean and standard deviation based on frequency. Rutgers University (2013) stated that frequency can be used to describe the number of times or how frequently a category, score, or range of scores occurs. From this, it can help the researcher to know the implementation by the teacher from high to low. 


\section{Findings}

Table 1

The implementation of Supermind Textbook

\begin{tabular}{|c|c|c|c|c|c|c|}
\hline No. & ITEMS / SCALES & $\begin{array}{l}\text { Strongly } \\
\text { Agree } \\
(\%)\end{array}$ & $\begin{array}{l}\text { Agree } \\
(\%)\end{array}$ & $\begin{array}{l}\text { Neutral } \\
(\%)\end{array}$ & $\begin{array}{l}\text { Disagree } \\
(\%)\end{array}$ & $\begin{array}{l}\text { Strongly } \\
\text { Disagree } \\
(\%)\end{array}$ \\
\hline 1. & The textbook focus on speaking skill. & 26.6 & 57.8 & 15.6 & 0 & 0 \\
\hline 2. & $\begin{array}{l}\text { Topics for speaking skill are various } \\
\text { and relevant. }\end{array}$ & 12.5 & 71.9 & 15.6 & 0 & 0 \\
\hline 3. & $\begin{array}{l}\text { There are sufficient exercises for } \\
\text { listening. }\end{array}$ & 15.6 & 62.5 & 15.6 & 6.3 & 0 \\
\hline 4. & $\begin{array}{l}\text { The difficulty level of the listening } \\
\text { exercises matches the level of } \\
\text { students. }\end{array}$ & 9.4 & 6.3 & 18.8 & 65.6 & 0 \\
\hline 5. & $\begin{array}{l}\text { The length of the reading texts } \\
\text { matches the level of students. }\end{array}$ & 17.2 & 54.7 & 25 & 3.1 & 0 \\
\hline 6. & The reading texts are authentic. & 3.2 & 25.4 & 25.4 & 46.0 & 0 \\
\hline 7. & $\begin{array}{l}\text { There are sufficient exercises for } \\
\text { writing. }\end{array}$ & 3.1 & 54.7 & 32.8 & 6.3 & 3.1 \\
\hline 8. & $\begin{array}{l}\text { The writing topics are in line with the } \\
\text { topics of units. }\end{array}$ & 9.4 & 62.5 & 25 & 3.1 & 0 \\
\hline 9. & $\begin{array}{l}\text { Presenting new words using pictures } \\
\text { are suitable for students. }\end{array}$ & 9.4 & 62.5 & 25 & 3.1 & 0 \\
\hline 10. & $\begin{array}{l}\text { The number of exercises to practice } \\
\text { the usage of new words is sufficient. }\end{array}$ & 29.7 & 57.8 & 12.5 & 0 & 0 \\
\hline 11. & $\begin{array}{l}\text { The difficulty level of the new words } \\
\text { matches the level of the students. }\end{array}$ & 12.5 & 50 & 34.4 & 3.1 & 0 \\
\hline 12. & $\begin{array}{l}\text { The grammar of each unit has been } \\
\text { sufficiently explained. }\end{array}$ & 9.4 & 50 & 34.4 & 3.1 & 3.1 \\
\hline 13. & $\begin{array}{l}\text { There are enough examples for each } \\
\text { grammatical structure. }\end{array}$ & 6.3 & 56.3 & 28.1 & 6.3 & 3.1 \\
\hline 14. & $\begin{array}{l}\text { There are some sections in the book } \\
\text { dedicated to pronunciation. }\end{array}$ & 9.4 & 68.8 & 18.8 & 3.1 & 0 \\
\hline 15. & $\begin{array}{l}\text { There are sufficient exercises for } \\
\text { pronunciation practice. }\end{array}$ & 9.4 & 60.9 & 23.4 & 6.3 & 0 \\
\hline
\end{tabular}

Table 1 shows a result on the implementation of Supermind Textbook. Based on the survey, as for the first item, there are $26.6 \%$ of the respondents strongly agreed that the textbook focus on speaking skill while $57.8 \%$ agreed with it and $15.6 \%$ have a neutral stand. On the other hand, majority of the respondents $(71.9 \%)$ agreed that topics for speaking skill are various and relevant followed with $15.6 \%$ that choose to be neutral. Meanwhile, the rest of the respondents, $12.5 \%$ strongly agreed with the item.

On the other hand, as for "There are sufficient exercises for listening" item, 62.5\% agreed with it. Besides, $15.6 \%$ of the respondents choose strongly agreed and to be neutral with the item while the rest of the respondents, $6.3 \%$ disagreed. Next, for the fourth item, $9.4 \%$ strongly agreed and most of the respondents with $6.3 \%$ agreed that the difficulty level 
of the listening exercises matches the level of students. However, $18.8 \%$ have neutral connotation and $65.6 \%$ disagreed with it.

In addition, most of the respondents with $54.7 \%$ agreed that the length of the reading texts matches the level of pupils while $17.2 \%$ strongly agreed and $25 \%$ have neutral stands. However, 3.1\% disagreed with it. Furthermore, as for the next item, 54.7\% choose agreed and $32.8 \%$ have neutral connotation. However, for sixth item, $46 \%$ of the respondents disagreed that the reading text is authentic while $3.2 \%$ strongly agreed and $25.4 \%$ choose to agree and be neutral. Besides, 6.3\% disagreed with the item. Yet, 3.1\% strongly agreed and strongly disagreed that there are sufficient exercises for writing.

Moreover, referring to Table 1, 9.4\% strongly agreed and $62.5 \%$ of the respondents agreed with "The writing topics are in line with the topics of units." In the meantime, 25\% choose to be neutral while 3.1\% disagreed. As for the ninth-item, majority of the respondents, $62.5 \%$ agreed and followed by $9.4 \%$ strongly agreed with the item. However, $25 \%$ have neutral stand and $3.1 \%$ disagreed with it.

Besides, based on the results, it showed that $29.7 \%$ strongly agreed that "The number of exercises to practice the usage of new words is sufficient." But, $57.8 \%$ agreed with it and $12.5 \%$ are neutral. From the study, there are $12.5 \%$ strongly agreed and followed by $50 \%$ agreed that "The difficulty level of the new words matches the level of the students." Yet, $34.4 \%$ are neutral while $3.1 \%$ disagreed.

There are $9.4 \%$ of the respondents who strongly agreed with the twelfth item. In the meantime, $50 \%$ are agreed with it and $34.4 \%$ choose to be neutral. Yet, $3.1 \%$ disagreed and strongly agreed that the grammar of each unit has been sufficiently explained. For the next item which is "There are enough examples for each grammatical structure", 6.3\% strongly agreed and $56.3 \%$ agreed with it, Yet, $28.1 \%$ of the respondents have neutral connotation while $6.3 \%$ disagreed and $3.1 \%$ strongly disagreed.

Based on the result for "There are some sections in the book dedicated to pronunciation item", majority of the respondents, $68.8 \%$ agreed followed by $18.8 \%$ have a neutral stand. However, 9.4\% had chosen strongly agreed and 3.1\% disagreed with the item. Finally, for the last item, $9.4 \%$ of the respondents choose to be strongly agreed while $60.9 \%$ agreed. Yet, $23.4 \%$ choose to be neutral and $6.3 \%$ disagreed that there are sufficient exercises for pronunciation practice.

\section{Discussions}

According to the result, it showed that majority of the respondents agreed that Supermind textbook is suitable to be implemented in the classroom as it is focused on speaking skills and the topics in the textbook are various and relevant to the students. For example, for Year 1 , the content focuses more on the self-introduction. This is aligned by Rodgriquez (2012) that mentioned, pupils will be able to involve and feel motivated to be active in the classroom activities when the topics are related to them and what they like and dislike. As the sentence structure related to themselves, it can help them to communicate with people that they had just met easily. This is related to one of Second Language Acquisition, which is Communicative Language Teaching. This theory emphasized that pupils should be able to apply the knowledge that they had learnt and use it in their daily life.

As pronunciation is one of the elements included in speaking skills, $68.8 \%$ of the respondents agreed that there are some sections in the book dedicated to pronunciation while $60.9 \%$ also choose to agree that there are sufficient exercises for pronunciation 
practice. As English language has a different way in pronouncing a word, thus, it is necessary for the pupils to learn the correct way on how to pronounce the words correctly. This is because, without a correct pronunciation, the pupils will have difficulty when they want to communicate with other people in the future. Not only that, it might also cause misunderstanding as the other party will unable to understand the message correctly.

In addition, 62.5\% agreed that the textbook has enough exercises for listening skill. However, $65.6 \%$ disagreed that the exercises matched with the level of the students. As the textbook is complement with CDs, it helps the teachers to use the content from the textbook to assess their students. However, as listening is the most challenging part, it is necessary for the exercises in the textbook able to be used in helping the pupils to improve their listening skill (Trisha, 2016). Besides, as English is a second language in Malaysia, it is good that the pupils had a lot of exposure in listening to audio from the target language. As mentioned by The Open University, to be successful in listening skills, it will be acquired over time and with lots of practice. This will help them to recognize and familiar with the language especially on the pronunciation.

Next, as for reading skill, the data collected showed that the respondents agreed that the length of the reading texts in Supermind textbook matches the level of the students. However, it is not authentic enough for the students. According to Trisha (2016), pupils should be able to feel encouraged by the contents. This will help them to improve and increase their vocabulary. Hence, it is important for teachers to use text that is authentic enough for the pupils to be used in the classroom during reading lesson. Teachers can use their knowledge to adapt and adopt the reading text from Supermind textbook based on the level of their students. This can benefit the pupils in term of enjoying the reading lesson as they can fully participate and understand the text.

Additionally, $62.5 \%$ of the respondents agreed that the writing topics are in line with the topics of units. This is crucial because it can help to enhance the students' creativity and can act as a guideline for them to write. Based on Stosky (1983) and Krishen (1984), a good textbook is a textbook that can help the pupils to write and be used as a guideline for them to write creative works. For instance, if the teacher wanted his or her pupils to write about their favourite food, they can find ideas by using pictures and text from Chapter 5 in Supermind.

Furthermore, the respondents also agreed that the pictures used in the textbook are suitable and presenting the new words besides those pictures are also suitable with the students. This is important so that the pupils able to recognize and remember the words easily. For instance, for At School, pupils able to learn about stationery based on the pictures that complement each word. This is related to theory by Piaget that mentioned photographs, maps, and graphics organizers able to help young learners to visualize the words into real-life situations. Not only that, when the pupils able to register the new words, it also can help them in their reading skills. This is aligned with Misbah et al (2017), that mentioned when pupils have low level of word register it can cause them to have difficulty in acquiring other language skills. This will cause the pupils to be demotivated in learning English Language.

Moreover, the textbook also includes grammar. Based on the results, $50 \%$ and $56.3 \%$ of the respondents agreed that the grammar in each unit has been explained and there are enough examples for each grammatical structure. For instance, those examples are given in the form of a dialogue which is in a fun and interactive way. Thus, pupils able to use their knowledge that they gain from the textbook and prevent themselves from making grammar 
mistakes whether when communicate orally or in writing. This shows that grammar is one of the important elements in learning English language. As grammar is a complex structure, those examples able to help the pupils to understand how to use the grammar easily in a social context. This is related to Creative Construction Theory or Naturalistic Approach where acquisition of the language should be subconscious process which helps pupils to be fluent in the target language.

\section{Conclusion}

To sum up, based on the data gathered from the survey, there are some contents in the textbook that are suitable and can be implemented in the classroom to teach the pupils on the skills. However, there are some characteristics of Supermind textbook that contributes to the challenges that teachers need to face during implementing it, especially on the practical concerns. Therefore, it is essential for some adjustment and modification that need to be done by Malaysian syllabus designers and the policymakers to overcome the shortcomings and weaknesses. During the process of revising the textbooks, the good qualities of the textbooks can be maintained meanwhile the weaknesses of the textbook should be eliminated or adjusted. It is suggested that the textbook authors to take count the latest trends in education but at the same time still maintain the culture and background of the learners so that the same problem will not occur for the revised textbook.

Lastly, it is hope that by using Supermind textbook, it can help the pupils in second language acquisition. When the pupils have enough exposure to the language, he or she will be able to remember the language and use it automatically and able to improve him or herself to learn more complicated language skills. This is aligned with Communicative Language Theory which emphasized that when the students have language competence, they will be able to apply the knowledge and use the target language confidently. Thus, in order to achieve it, teachers need to use varieties theories and strategies in implementing the textbook in the classroom so that the students will be able to master the language in a non-stressful environment.

\section{References}

Alderson, J. C. (2016). The Shaky Ground beneath the CEFR: Quantitative and Qualitative Dimensions of Language Proficiency. The Modern Language Journal, 91(4). http://www.jstor.org/stable/4626093

Behnke, Y. (2018). Textbook Effects and Efficacy: The Palgrave Handbook of Textbook Studies. Palgrave Macmillan

Cheng, W. W., Hung, L. C., \& Chieh, L. C. (2011). Thinking of the Textbook in the ESL/EFL Classroom. Canadian Center of Science and Education, 4(2). www.ccsenet.org/elt

Chin, C. (2018). A roadmap to better English. The Star Online. https://www.pressreader.com/malaysia/thestarmalaysia/20180204/282754882147582

Cunningsworth, A. (1995). Choosing your coursebook. Heinmann.

Hong, Y. (2008). On teaching strategies in second language acquisition, 5(1)

Hulstijn, J., Alderson, C., \& Schoonen, R. (2010). Developmental stages in second language acquisition and levels of second language proficiency: are there links between them? Johnson, H. (2011). Books vs. Internet: Whose Information Is More Accurate? 
http://publishingperspectives.com/2011/10/books-vs-internet-more accurate/\#.Vvgqw_196Uk.

Kilickaya, F. (2004). Authentic materials and culture content in EFL classrooms. The Internet ELT Journal, 10(7).

Krashen, S. (1984). Writing Research, Theory and Applications. Prentice Hall.

Lamie, J. M. (1999). Making the textbook more communicative. The Internal TESL Journal. 5(1). www.iteslj.org

Lappalainen, T. (2011). Presentation of The American Culture in EFL Textbooks: An Analysis of The Cultural Content of Finnish EFL Textbooks for Secondary And Upper Secondary Education

Mbuva, J. (2016). Exploring Teachers' Self-Esteem and Its Effects on Teaching Students' Learning and Self-Esteem. Journal of Higher Education Theory and Practice, 16(5): 63

Ministry of Education. (2015). English Language Education Reform in Malaysia: The Roadmap 2015- 2025.

Muijs, D. (2011). Doing Quantitative Research in Education with SPSS. 2nd Ed. SAGE Publications Inc.

Munn, P., \& Dreyer, E. (1990). Using Questionnaires in Small-Scale Research: A Teachers' Guide. Jones TL.

Nguyen, T. M. (2015). Textbook evaluation: the case of English textbooks currently in use at Vietnams upper-secondary school.

https://www.researchgate.net/publication/275644512

Rahimpour, M., \& Hashemi, R. (2011). Textbook Selection and Evaluation in EFL Context World. Journal of Education, 1(2)

Razmjoo, S. A. (2007). High schools or private institutes textbooks? Which fulfill

Richards, J. (2012). The Role of Textbooks in a Language Program. http://www.professorjackrichards.com/work.htm.

Rutgers University (2013). https://www.rutgers.edu/

Sànchez, J. R. (2018). Language Teaching: Task-supported Textbook Redesign

Schulten, K. (2013). How Do You Know if What You Read Online Is True? http://learning.blogs.nytimes.com/2013/12/11/how-do-you-know-if-what-you-readonline-is-true/?_r=0

Stefánsson, E. G., \& Jóhannsdóttir, L. A. (2013). Second Language Acquisition the Effect of Age and Motivation SLA: Motivation and The Age Factor.

Stotsky, S. (1983). Research on Reading / Writing Relationships: A Synthesis and Suggested Directions. Language Arts. 60, 627-642

Trisha, A. H. (2016). A Study on the role of textbooks in second language acquisition communicative language teaching. Asian EFL Journal, 9(4), 126-140.

Uri, N. F. M., \& Aziz, M. S. A. (2018). Implementation of CEFR in Malaysia:Teachers' awareness and the Challenges. 3L: The Southeast Asian Journal of English Language Studies, 24(3), 168 - 183, http://doi.org/10.17576/3L-2018-2403-13

Rodríguez, M. (2012) The importance of teaching listening and speaking skills The Open University (n.d) Teacher Education through School-based Support in India. Strategies for teaching listening. https://www.open.edu/openlearncreate/pluginfile.php/134891/mod_resource/cont ent/3/SE08_AIE_Final.pdf

Misbah, N. H., Mohamad, M., Yunus, M. M., \& Ya'acob, A. (2017). Identifying the Factors 
INTERNATIONAL JOURNAL OF ACADEMIC RESEARCH IN PROGRESSIVE EDUCATION AND DEVELOPMENT

Vol. 10, No. 3, 2021, E-ISSN: 2226-6348 @ 2021 HRMARS

Contributiong to Students' Difficulties in the English Language Learning. Scientific Research, Vol. 8 (13). 